\title{
Teacher's Perception of Self-Directed Learning and EFL Students' Learning Autonomy during COVID-19 Pandemic
}

\author{
M. Damayanti ${ }^{1 *}$, L. P. Artini ${ }^{2 *}$, L. G. E. Wahyuni ${ }^{3 *}$ (D) \\ 1,2,3 English Language Ganesha University of Education, Bali, Indonesia
}

\section{A R T I C L E I N F O}

Article history:

Received February 10, 2021

Revised February 13, 2021

Accepted June 17, 2021

Available online August 25, 2021

Kata Kunci:

Pembelajaran online, pembelajaran mandiri,

persepsi guru

Keywords:

Online learning, self-directed

learning, teacher's perception

DOI:

http://dx.doi.org/10.23887/jpbi.v9 i2.32014

\begin{abstract}
A B S T R A K
Pandemi COVID-19 memaksa institusi akademik di Indonesia menerapkan pembelajaran online. Akibatnya, guru harus menyiapkan strategi pembelajaran online yang dapat membangun pembelajaran mandiri siswa. Penelitian ini bertujuan untuk menganalisis persepsi guru tentang pembelajaran mandiri, aktivitas yang ditugaskan dalam pembelajaran online, dan komponen pembelajaran mandiri dalam aktivitas. Penelitian ini menggunakan pendekatan metode embedded mixed. Metode yang digunakan untuk mengumpulkan data yaitu observasi, wawancara dan kuesioner. Instrument yang digunakana untuk mengumpulkan data yaitu kuesioner self-rated, tabel observasi, dan tabel klasifikasi. Teknik yang digunakan dalam menganalisis data yaitu statistic deskriptif kualitatif dan kuantitatif. Hasil penelitian ini menunjukkan bahwa guru merasa dirinya memiliki pengetahuan tentang dan dalam melaksanakan Self-Directed Learning. Guru melakukan proses pembelajaran dalam tiga bagian, yaitu pra kegiatan, kegiatan awal, dan pasca kegiatan. Namun, hanya ada tiga komponen Self-Directed Learning yang diikutsertakan dalam kegiatan tersebut. Dalam kegiatannya, self-directed learning tercermin ketika guru memberikan materi, tugas individu, dan bantuan kepada siswa bila diperlukan. Namun, pembelajaran mandiri tidak tercermin lagi pada pasca kegiatan karena tidak ada refleksi atau umpan balik yang diberikan kepada siswa. Diperlukan kegiatan pembelajaran yang lebih efektif dan menarik.
\end{abstract}

\section{A B S T R A C T}

The COVID-19 pandemic has forced academic institutions in Indonesia to implement online learning. As a result, teachers must prepare online learning strategies that can build students' independent learning. This study aims to analyze teacher perceptions of independent learning, assigned activities in online learning, and independent learning components in activities. This study uses an embedded mixed-method approach. The methods used to collect data are observation, interviews, and questionnaires. The instruments used to collect data are self-rated questionnaires, observation tables, and classification tables. The technique used in analyzing the data is descriptive qualitative and quantitative statistics. The results of this study indicate that teachers feel they have knowledge about and in implementing Independent Learning. The teacher carries out the learning process in three parts: pre-activity, initial activity, and post-activity. However, there are only three components of Self-Directed Learning that are included in the action. In its activities, self-directed learning is when the teacher provides material, individual assignments, and assistance when needed. However, independent learning is no longer a reflection on post-activity because there is no feedback. Therefore, more effective and exciting learning activities are required.

This is an open-access article under the CC BY-SA license.

Copyright @ 2021 by Author. Published by Universitas Pendidikan Ganesha.

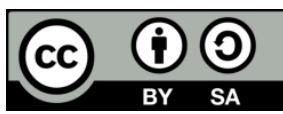

\section{INTRODUCTION}

Looking at the current situation of the COVID-19 pandemic, Indonesia is one of the countries affected in the education system sector by the pandemic (Hermanto et al., 2021; Nugroho et al., 2021). Many families still find difficulties in carrying out studies from home. Most of them are caused by students' readiness in selfstudy and inadequate facilities (Syauqi et al., 2020; Wijaya et al., 2020). The situation forces the educational system of Indonesia to implement online learning (Nartiningrum \& Nugroho, 2020; Yulia, 2020). This problem was also found in one high school. Based on the results of observations made at SMA 5 Denpasar, it was found that teachers still had difficulty determining the right learning strategies to be applied in online learning. In addition, students also still have less interest in learning when learning is done independently. This will have an impact on the decreased ability of students. Therefore, the need of a learning strategy that can build self-directed learning on each student becomes more important to be taught to the students (Devi et al., 2016; Saiboon et al., 2021). The importance of self-directed learning in the current situation for students is that they can learn independently in any condition, whether in the online class or actual face-to-face meetings. 
As mentioned in the statement above, to develop students' learning independence, they should have more exposure to 4C's learning skills of $21^{\text {st }}$-century learning (Gürsoy, 2021; Gustavo, 2010). Those skills are critical thinking, creativity, collaboration, and communication (Bedir, 2019; Churchill et al., 2013). Looking at each skills definition, critical thinking is the skill in finding the roots of the problems and observing misconceptions. Students can improve their critical thinking by reading books, asking questions, and giving opinions with different perspectives (Asyari et al., 2016; Seibert, 2020). Creativity means creative thinking to create something new. Creative thinking can be done by imagining situations and events that will produce tentative explanations or solutions also create something new (Ulinnuha et al., 2021; Zhou et al., 2013). Students can increase their creative skills through a project or brainstorming (Bystrova \& Larionova, 2015; Wijayanti et al., 2016). Collaboration skill is an engagement working skillfully in a group. In collaboration, students share their ideas, making a decision, problem-solving, contributions, and facilitator in group work to achieve their goals (Farsani et al., 2021; Nordgren et al., 2021). Communication is the ability to communicate verbally to others. Through voice, suitable intonation, expression, gesture, and body language can increase students' skill of communication (Coffelt et al., 2019). Therefore, it can be observed that those skills are relevant in projecting the students to independent learning because the skills can assist the students' autonomy in learning.

To provide the students with the four learning skills that can help students' autonomy in learning, teachers have to find a suitable strategy and improve their motivation and interest in learning (Kembara et al., 2018; Márquez-García et al., 2020). One of the learning strategies that can help students solve problems is SelfDirected Learning (Hawkins, 2018; Van der Walt, 2016). To accomplish it, the teacher should prepare a kind of techniques that they can use for Self-Directed Learning. All of the participants (teacher and students) must support each other and play their role. Teachers, in particular, must be equipped with new knowledge and skills in teaching and learning that are relevant to the development and needs in $21^{\text {st }}$ century learning, so then they could provide the students with effective learning strategy to help them acquire the skills for self-directed learning (Geng et al., 2019). Self-Directed Learning is a learning process where the learners' control their own knowledge as it represents an essential working in our modern world (Taufiq et al., 2020; Tjakradidjaja et al., 2016). Self-directed learning is a concept of individual control of their choices which is the best way of learning. They learn by their responsibility with guidance from the teacher or instructor. Self-directed learning is also known as self-planned learning or independent learning, which is a process where learners take their own responsibility (Hanik, 2020; Humaira \& Hurriyah, 2018). Self-Directed learning also affects the critical thinking of the students, and it influences the other aspects of education (Sert \& Boynueğri, 2017).

Relating to the students' learning autonomy, the goal of Self-Directed Learning is to help learners to develop self-sufficiency in the learning process (Hill et al., 2020; Zhu et al., 2020). Self-directed learners who can learn autonomously select, manage, and assess their learning activities, creating flexibility since they can do that at any time and in any place (Alonderiene \& Suchotina, 2017; Shaalan, 2019). Self-directed learners are characterized by their ability to take responsibility for learning, define their learning objectives, effectively use language learning materials, organize learning schedules, and develop appropriate learning strategies that can best meet their needs (Andersen \& Watkins, 2018; Chou, 2013). The relation between learning autonomy and self-directed learning strengthens the importance of self-directed learning as a strategy that can help students acquire the skills needed in the $21^{\text {st }}$ century.

In order to implement Self-Directed Learning, several techniques can be used, one of the examples is using projects (Wichadee, 2011). Students can construct their own knowledge through active involvement in learning projects (Wichadee, 2011). Besides, the teacher also can provide the students with homework. Evidence shows that students will be more motivated in doing assignments as well as gaining perseverance (Hong et al., 2015; Logan et al., 2021). Considering teachers' role in Self-Directed Learning, this current study tries to figure out teachers' perception toward self-directed learning and the strategies that can be applied in supporting students' learning autonomy or self-directed learning.

The study was conducted at SMA Negeri 5 Denpasar because teachers in this school had been experienced in working a learning process that involves activities that could engage the students to learn independently. From this point, teachers in this school were suitable for the research as they were knowledgeable in independent learning. Besides, as the current situation did not allow the students and teachers to come to school, they would conduct independent learning frequently, which meant that this school was well-suited with this study - analyzing teachers' perceptions of self-directed learning in teaching English, analyzing the activities assigned by English teachers in dealing with online learning, and analyzing the components of self-directed learning that can be identified at SMA Negeri 5 Denpasar. To determine the activities that belonged to selfdirected learning, it was essential to relate the activities assigned by the teachers with the components of selfdirected learning. Therefore, through those purposes, the study would generate a reliable perception of selfdirected learning from the English teachers in SMA Negeri 5 Denpasar. 


\section{METHOD}

This study used an embedded mixed-method approach which is a concept that supports a primary category of data. In this research, it was chosen to incorporate embedded mixed method because qualitative and quantitative data were required. SMAN 5 Denpasar, Bali was chosen as the setting of the study with an English teacher as the subject of the study.

The data were collected through questionnaires and observation. The questionnaire was developed in accordance to the theory and was used as an instrument to collect the data related to the teacher's perception about her knowledge, impact, and implementation of self-directed learning in online learning (Tan \& Koh, 2014). The observation was conducted to investigate and describe the learning activities undertaken by the teacher and the students. Therefore, the instruments used to collect the data were a self-rated questionnaire, observation table, and identification table. After the data were collected, the data were then analyzed using interactive model analysis. The questionnaire comprised 11 statements for the knowledge factor, 28 statements for the implementable factor, and 9 statements for the influential factor. Five choices with score 1 to 5 were given for every information. After calculating the scores in every type of content Self-Directed Learning, those scores were summed up and averaged to obtain the score in every self-rated questionnaire.

There were 5 criteria for content knowledge of Self-Directed Learning adapted: no knowledge, lack of knowledge, moderately knowledgeable, knowledgeable, and very knowledgeable Sugiono (2015). There were also 5 criteria for the teacher's implementation of self-directed learning that was adapted namely nonanticipative, lack of anticipative, moderately anticipative, anticipative and very anticipative Sugiono (2015). Same as the previous, the lowest criteria table was non-anticipative with a range scale of 1 to 1.5 ; meanwhile, the highest criteria was very anticipative with a range score of 4.6 to 5.0. Those criteria referred to the impact of implementing self-directed learning in online learning. The highest and lowest scores were similar to the two table before, which were strongly influential with scores 4.6 to 5.0 and uninfluential with scores of 1.0 to 1.5.

\section{RESULT AND DISCUSSION}

\section{Result}

It is important to note that the first research question investigated the teacher's perception of selfdirected learning, which were related to her knowledge, implementation, and impacts of self-directed learning. The findings indicated that the English teacher responded to all of the statements in the questionnaire with the total score of 42 and the average of 3.81. Therefore, the English Teacher of SMAN 5 Denpasar considered herself as knowledgeable in terms of the content knowledge of self-directed learning.

In the implementation, there were 28 statements based on 6 indicators from Tan's theory (2015) which include providing learner autonomy in task design, involving student in identifying learning gaps, facilitating students to investigate inquiry, goal setting and planning, providing scaffolds for students' self-monitoring, monitoring students' learning and providing just-in-time assistance, engaging students in reflection of learning, engaging students' prior knowledge and allowing them to make connections of what they learn inside and outside of the school.

The findings showed that the English Teacher completed all the implementation statements by giving some scores of 3,4, and 5. The teacher responded to all statements with a total score of 123 , and the average score was 4.39. Therefore, the English Teacher of SMAN 5 Denpasar categorized herself as anticipative in content implementation of self-directed learning.

In the impact aspect, there were 9 statements based on 6 indicators of Tan's Theory. The English teacher considered self-directed learning as influential. It could be seen from the total score 36 that was gained from the score of 4 for most of the statements. The average impact aspect in Self-directed learning was 4.

The activities were observed through observations that were conducted five times. The findings showed that the teacher assigned the activities in each observation with 3 main activities: pre-activity, whilst activity, and post-activity. It could be seen that the activities posted by the teacher in online teaching and learning in five meeting. All of the observation was conducted in the class of X MIPA 1 SMA Negeri 5 Denpasar. Table 4 shows the activities assigned by the teacher during the online learning process.

Table 4. Activities Assigned by the Teacher during the Online Learning Process

\begin{tabular}{lll}
\hline Observation & Lesson Segment & Activities assigned by the teachers \\
\hline Observation 1 & Pre-activity & $\begin{array}{l}\text { Students filled the attendance list through Google Forms in } \\
\text { "pronouns" }\end{array}$ \\
& Whist-activity & $\begin{array}{l}\text { Students did assignment given in Google Classroom } \\
\text { Students submitted their work to the submission room in }\end{array}$
\end{tabular}




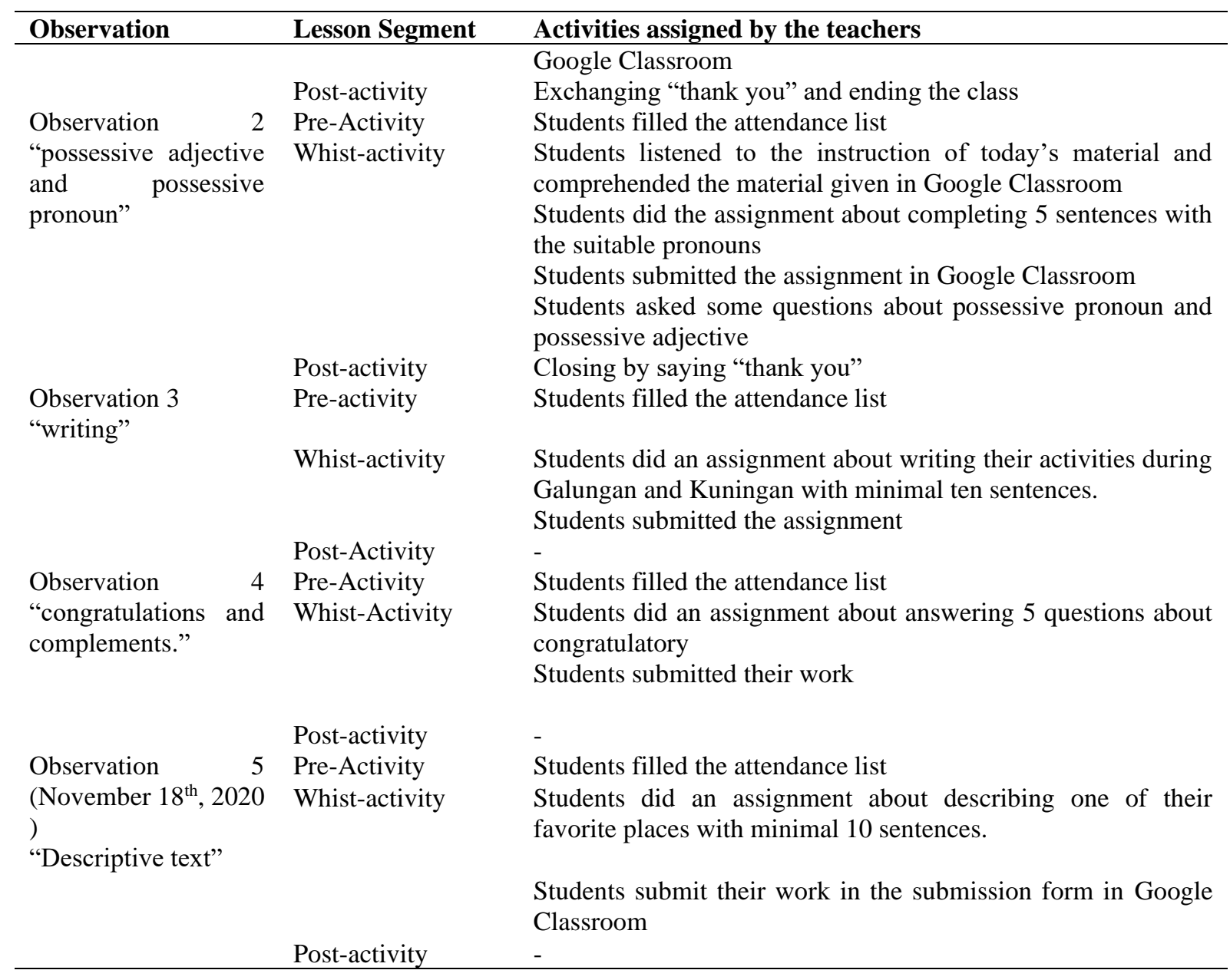

The findings indicated that the English teacher responded to all of the statements in the questionnaire with the total score of 42 and an average of 3.81. Therefore, the English Teacher of SMAN 5 Denpasar considered herself as knowledgeable in the content knowledge of self-directed learning. The findings showed that the English Teacher completed all the implementation statements by giving some variations score, such as 3, 4, and 5. The teacher responded to all statements with total score of 123 and the average of score was 4.39 . Therefore, the English Teacher of SMAN 5 Denpasar categorized herself as anticipative in terms of content implementation of self-directed learning. In the impact aspect, there were 9 statements based on 6 indicators of Tan's Theory. The English teacher considered self-directed learning as influential. It could be seen from the total score 36 that was gained from the score of 4 for most of the statements. The average of impact aspect in Self-directed learning was 4 . The findings further indicated that the teacher knew how to give self-directed learning through her implementation in online education. By providing understanding independently, teachers were able to create students who were ready to face 21 st-century learning.

\section{Discussion}

The first observation with "Pronouns" as the topic. In the pre-activity, the teacher greeted the students through WhatsApp group by saying "morning" to the students, then asked them to fill the absence list on Google Classroom. After that, the students listened to the instruction to write and answer the Google Classroom task. This activity does not contain self-directed learning. The beginning of self-directed learning should be started with apperception to mentally and physically prepare the students to learn (Hawkins, 2018; Van der Walt, 2016). Since the pre-activity did not include apperception or any kinds of activities that could first prepare the students to learn, it does not reflect self-directed learning (Geng et al., 2019; Taufiq et al., 2020).

After the pre-activity, the teacher continued with the whist activity that was shared on Google Classroom. The teacher gave the whist activity assigned by posting the task about "pronouns" through Google Classroom. The task was about completing 10 sentences by using the right subjective pronoun given in the form of a PDF in Google Classroom. By looking at the whist activity on observation 1, it could be seen that the teacher already practice self-directed learning as the teacher only gave the task without including the material of 
"pronouns". The practice is in line with the theory, whereas the teacher needs to monitor students' learning and provide just-in-time assistance when needed and provide scaffolds for the students. After the whist activity, the teacher-led to a post-activity (Hanik, 2020; Tjakradidjaja et al., 2016).

In the post-activity, there was no learning related to the activity done by in the post-activity session. Teacher only closed the meeting by greeting the students, and students answered it by saying "thank you." The teacher did not give students tasks; therefore, there was no feedback at the end of the activity. This activity does not reflect the practice of self-directed learning (Humaira \& Hurriyah, 2018; Sert \& Boynueğri, 2017). The last phase of the learning process must engage the students in reflection of learning, engage their prior knowledge, and draw the connection of what they learn inside and outside of the school (Hill et al., 2020; Zhu et al., 2020). Since the post-activity only ended up with the teacher and the students exchanging greetings, the process of selfdirected learning was not happening.

From observations I-V, the teacher did not implement self-directed learning effectively. It was because there was only 3 component of self-directed learning that could be implemented. Based on the results of the observation table, in the pre-activity, the teacher only assigned the greeting and absences list through Google Form. The vital activity in pre-activity was preparing before jumping into the material; the students needed to be physically and mentally ready for online learning activity (Alonderiené \& Suchotina, 2017; Shaalan, 2019). The teacher should give apperception like giving pictures or quiz in the pre-activity to attract students' attention (Setiyani et al., 2020; Taylor et al., 2017).

The absence of interaction in the classroom could make the students quickly getting bored, by providing interaction with students can encourage courage in discussing and sharing (Komalasari \& Rahmat, 2019; Yulando et al., 2019). The examples of assignments given by the teacher to students were writing their activities during Galungan and Kuningan with a minimum of ten sentences. This task already reflected a component in self-directed learning, namely provide autonomy task design (Taufiq et al., 2020; Tjakradidjaja et al., 2016). This activity was vital because it aimed to ascertain whether students could participate in online learning or lazing around because no one was watching them. Meanwhile, in the post-activity section, the teacher did not do any activities in closing the lesson. This segment referred to check their understanding of the material that had been taught previously. In general, post-activity provided opportunities for students to reflect and even students could share their knowledge with other students during learning activities (Khakiim et al., 2016). The conclusion showed that the teacher carried out no activity in the post-activity segment in each observation.

As shown in the observation findings, the activities in the implementation of self-directed learning focused on three main activities: pre-activity, whilst-activity, and post-activity. It can be seen that there was only a greeting section and filling the absences in the pre-activity. It certainly did not show Self-directed learning based on Tan's Theory (Tan \& Koh, 2014). In the second activity, students did an assignment in Google Classroom, it showed that the existed components based on Tan's theory of Self-directed learning involved students in identifying the learning gaps. The element of involved students in identifying learning gaps meant that the teacher instructed students to read their assignments and then worked on them without teaching them at first (Hanik, 2020; Humaira \& Hurriyah, 2018). The teacher could also ask them to answer questions to measure the level of students' understanding in doing the task. The purpose of this component was to determine students' knowledge without being taught it first.

In the observations made previously, the teacher always gave assignments without giving prior explanation to students to encourage students into student-centered learning and let them understand about their assignments. In the third activity, there was no existed component of Self-directed learning. The last activity was the students did the discussion based on their questions for the teacher if they still confused about the material. It could be seen that the existed components were monitoring students' learning and providing just-in-time assistance. Based on the activities assigned in the online teaching and learning process, three Self-Directed Learning components could be identified based on Tan's theory. Those indicators included providing autonomy task design, involving students in identifying learning gaps, monitoring students' learning, and providing just-intime assistance (Hill et al., 2020; Sert \& Boynueğri, 2017). In the context of autonomous learning and selfdirected learning, some of the teachers' activities have already promoted autonomous learning to the students (Alonderienè \& Suchotina, 2017; Zhu et al., 2020). The activities include giving and explaining materials, assigning the students with the individual and independent task, and providing assistance to the students when they were in need (Shaalan, 2019).

However, the findings also indicated that the application of Self-Directed Learning in the online learning was still not maximal. The questionnaire results showed that the teacher considers herself to have good knowledge in Self-Directed Learning, but in fact, the teacher only applied three indicators of Self-Directed Learning adapted from Tan (2014). However, instead of only listening and depending on the teacher, they need to be encouraged to be more active by being involved in discussion related to something fun to learn. Therefore, from the results, it can be said the self-directed components used in the activities were not optimal yet. 
Therefore, the teacher needs to provide further components to encourage the students to be autonomous, selfdirected learners.

\section{CONCLUSION}

The questionnaire result showed that the teacher perceived herself to be knowledgeable about perceptions in the content of knowledge of self-directed learning, anticipative in implementing self-directed learning in online education, and influential in learning in self-directed learning. The results indicated that the teacher already understood the use of self-directed learning in the learning process, especially in COVID-19. The observation revealed that the teacher conducted learning activities divided into three: pre-activity, whist activity, and post-activity. In the whist activity, self-directed learning was reflected as the teacher gave students materials, individual tasks, and assistance when needed. However, self-directed learning was not reflected again on the post-activity as there was no reflection nor feedbacks provided for the students.

\section{REFERENCES}

Alonderienè, R., \& Suchotina, N. (2017). The Impact of Self-directed Learning on Work Performance of Lawyers. Organizations And Markets In Emerging Economies, 8(2). https://doi.org/10.15388/omee.2017.8.2.14185

Andersen, T., \& Watkins, K. (2018). The value of peer mentorship as an educational strategy in nursing. Journal of Nursing Education, 57(4), 217-224. https://doi.org/10.3928/01484834-20180322-05

Asyari, M., Henie, M., Muhdhar, I. Al, \& Ibrahim, H. S. (2016). Improving critical thinking skills through the integration of problem based learning and group investigation. International Journal for Lesson and Learning Studies, 5(1), 36-44. https://doi.org/10.1108/IJLLS-10-2014-0042

Bedir, H. (2019). Pre-service ELT teachers' beliefs and perceptions on 21st century learning and innovation skills (4Cs). Journal of Language and Linguistic Studies, 15(1), 231-246. https://doi.org/10.17263/j1ls.547718

Bystrova, T., \& Larionova, V. (2015). Use of Virtual Mind Mapping to Effectively Organise the Project Activities of Students at the University. Procedia-Social and Behavioral Sciences, 214. https://doi.org/10.1016/j.sbspro.2015.11.724

Chou, P.-N. (2013). Students Perceptions Of Success In The Online Graduate-Level Classes: A Self-Directed Learning Perspective. Contemporary Issues in Education Research (CIER), 6(1), 115. https://doi.org/10.19030/cier.v6i1.7610

Churchill, D., King, M., \& Fox, B. (2013). Learning design for science education in the 21st century. Zbornik Instituta Za Pedagoska Istrazivanja, 45(2), 404-421. https://doi.org/10.2298/ZIPI1302404C

Coffelt, T. A., Grauman, D., \& Smith, F. L. M. (2019). Employers' Perspectives on Workplace Communication Skills: The Meaning of Communication Skills. Business and Professional Communication Quarterly, 82(4), 418-439. https://doi.org/10.1177/2329490619851119

Devi, S., Bhat, Ks., Ramya, S., Ravichandran, K., \& Kanungo, R. (2016). Self-directed learning to enhance active learning among the 2nd -year undergraduate medical students in Microbiology: An experimental study. Journal of Current Research in Scientific Medicine, 2(2), 80-83. https://doi.org/10.4103/24553069.198379

Farsani, M. A., Jamali, H. R., Beikmohammadi, M., Ghorbani, B., \& Daneshvar, L. S. (2021). Methodological orientations, academic citations, and scientific collaboration in applied linguistics: What do research synthesis and bibliometrics indicate? System, 100. https://doi.org/10.1016/j.system.2021.102547

Geng, S., Law, K. M. Y., \& Niu, B. (2019). Investigating self-directed learning and technology readiness in blending learning environment. International Journal of Educational Technology in Higher Education, 16(1), 17. https://doi.org/10.1186/s41239-019-0147-0

Gürsoy, G. (2021). Digital storytelling: Developing 21st century skills in science education. European Journal of Educational Research, 10(1), 97-113. https://doi.org/10.12973/EU-JER.10.1.97

Gustavo, N. S. (2010). A 21st-Century Approach to Health Tourism Spas: The Case of Portugal. Journal of Hospitality and Tourism Management, 17(1). https://doi.org/10.1375/jhtm.17.1.127

Hanik, E. U. (2020). Self directed learning berbasis literasi digital pada masa pandemi covid-19 di Madrasah Ibtidaiyah. ELEMENTARY: Islamic Teacher Journal, 183. https://doi.org/10.21043/elementary.v8i1.7417

Hawkins, M. W. (2018). Self-directed learning as related to learning strategies, self-regulation, and autonomy in an English language program: A local application with global implications. Studies in Second Language 
Learning and Teaching, 8(2), 445-469. https://doi.org/10.14746/ssllt.2018.8.2.12

Hermanto, Y. B., Agustini, V., \& Srimulyani. (2021). The Challenges of Online Learning During the Covid-19 Pandemic. Jurnal Pendidikan Dan Pengajaran, 54(1). https://doi.org/10.23887/jpp.v54i1.29703

Hill, M., Peters, M., Salvaggio, M., Vinnedge, J., \& Darden, A. (2020). Implementation and evaluation of a selfdirected learning activity for first-year medical students. Medical Education Online, 25(1), 1-10. https://doi.org/10.1080/10872981.2020.1717780

Hong, E., Mason, E., Peng, Y., \& Lee, N. (2015). Effects of homework motivation and worry anxiety on homework achievement in mathematics and English. Educational Research and Evaluation, 21(7-8), 491514. https://doi.org/10.1080/13803611.2015.1131721

Humaira, S. A., \& Hurriyah, I. A. (2018). Students perspectives towards self-directed learning out of classroom. Advances in Social Science, Education and Humanities Research, 145, 7-11. https://doi.org/10.2991/iconelt-17.2018.2

Kembara, Rozak, \& Hadian. (2018). Research-based Lectures to Improve Students' 4C (Communication, Collaboration, Critical Thinking, and Creativity) Skills. Proceedings of the Second Conference on Language, Literature, Education, and Culture (ICOLLITE), 1(1). https://doi.org/10.2991/icollite$18.2019 .50, .20019 .11$.

Khakiim, U., Degeng, I. N. S., \& Widiati, U. (2016). Pelaksanaan Membuka Dan Menutup Pelajaran Oleh Guru Kelas 1 Sekolah Dasar. Jurnal Pendidikan: Teori, Penelitian, Dan Pengembangan, 1(9), 1730-1734.

Komalasari, K., \& Rahmat, R. (2019). Living Values Based Interactive Multimedia in Civic Education Learning. International Journal of Instruction, 12(1), 113-126. https://doi.org/10.29333/iji.2019.1218a

Logan, R. M., Johnson, C. E., \& Worsham, J. W. (2021). Development of an E-learning Module to Facilitate Student Learning and Outcomes. Teaching and Learning in Nursing, 16(2), 139-142. https://doi.org/10.1016/j.teln.2020.10.007

Márquez-García, M. J., Kirsch, W., \& Leite-Mendez, A. (2020). Learning and collaboration in pre-service teacher education: Narrative analysis in a service learning experience at Andalusian public schools. Teaching and Teacher Education, 96. https://doi.org/10.1016/j.tate.2020.103187

Nartiningrum, N., \& Nugroho, A. (2020). Online Learning amidst Global Pandemic : EFL Students' Challenges ,Suggestions , and Needed Materials. Academic Journal of English Language and Education, 4(2), 115140. https://doi.org/10.29240/ef.v4i2.1494

Nordgren, K., Kristiansson, M., Liljekvist, Y., \& Bergh, D. (2021). Collegial collaboration when planning and preparing lessons: A large-scale study exploring the conditions and infrastructure for teachers' professional development. Teaching and Teacher Education, 108. https://doi.org/10.1016/j.tate.2021.103513

Nugroho, A., Ilmiani, D., \& Rekha, A. (2021). EFL Teachers' Challenges and Insights of Online Teaching amidst Global Pandemic. Metathesis: Journal of English Language, Literature, and Teaching, 4(3), 277. https://doi.org/10.31002/metathesis.v4i3.3195

Saiboon, I. M., MSurg, Nurmaimun, Noriani, Shamsuddin, N. S., \& Johar, M. (2021). Effectiveness of SelfDirected Small-Group-Learning Against Self-Directed Individual-Learning Using Self-Instructional-Video in Performing Critical Emergency Procedures Among Medical Students in Malaysia: A Single-Blinded Randomized Controlled Study. Clinical Simulation in Nursing, 56(1). https://doi.org/10.1016/j.ecns.2021.02.006

Seibert, S. A. (2020). Problem-based learning: A strategy to foster generation Z's critical thinking and perseverance. Teaching and Learning in Nursing, 000, 2-5. https://doi.org/10.1016/j.teln.2020.09.002

Sert, N., \& Boynueğri, E. (2017). Digital technology use by the students and english teachers and self-directed language learning. World Journal on Educational Technology: Current Issues, 9(1), 24. https://doi.org/10.18844/wjet.v9i1.993

Setiyani, S., Fitriyani, N., \& Sagita, L. (2020). Improving student's mathematical problem solving skills through Quizizz. JRAMathEdu (Journal of Research and Advances in Mathematics Education), 5(3), $276-288$. https://doi.org/10.23917/jramathedu.v5i3.10696

Shaalan, I. E.-N. A. W. (2019). Remodeling teachers' and students' roles in self-directed learning. Journal of Language Teaching and Research, 10(3), 549-556. https://doi.org/10.17507/jltr.1003.19

Sugiono. (2015). Metode Penelitan Kuantitatif, kualitatif dan R\&D. Bandung: Alfabeta.

Syauqi, K., Munadi, S., \& Triyono, M. B. (2020). Students ' perceptions toward vocational education on online learning during the COVID-19 pandemic. Internasional Journal of Evaluation and Reseacrh In Education (IJEE), 9(4). https://doi.org/10.11591/ijere.v9i4.20766

Tan, L. (2015). Self-Directed Learning : Learning in the 21st Century. December.

Tan, L., \& Koh, J. H. (2014). Self-directed Learning: Learning in the 21st century. Singapore Ministry of Education.

Taufiq, M., Wijayanti, A., \& Fajriah, E. (2020). The implementation of e-comic earth layer to enhance students' self-directed learning. Journal of Physics: Conference Series, 1567, 022070. https://doi.org/10.1088/1742- 
$6596 / 1567 / 2 / 022070$

Taylor, A. T. S., Olofson, E. L., \& Novak, W. R. P. (2017). Enhancing student retention of prerequisite knowledge through pre-class activities and in-class reinforcement. Biochemistry and Molecular Biology Education, 45(2), 97-104. https://doi.org/10.1002/bmb.20992

Tjakradidjaja, F. A., Prabandari, Y. S., Prihatiningsih, T. S., \& Harsono, H. (2016). The role of teacher in medical student self-directed learning process. Journal of Education and Learning (EduLearn), 10(1), 7884. https://doi.org/10.11591/edulearn.v10i1.2992

Ulinnuha, R., Budi Waluya, S., \& Rochmad, R. (2021). Creative Thinking Ability With Open-Ended Problems Based on Self-Efficacy in Gnomio Blended Learning. Unnes Journal of Mathematics Education Research, 10(A), 20-25. https://journal.unnes.ac.id/sju/index.php/ujmer/article/view/34277

Van der Walt, H. (2016). The feasibility of grafting self-directed learning theory onto the capability theory. In E. Ments \& I. Oosthuizen (Eds.), Self directed learning research (pp. 1-34). AOSIS, Cape Town. https://doi.org/http://dx.doi.org/10.4102/ aosis.2016.sdlr14.01

Wichadee, S. (2011). Developing The Self-Directed Learning Instructional Model To Enhance English Reading Ability And Self-Directed Learning Of Undergraduate Students. Journal of College Teaching \& Learning (TLC), 8(12), 43. https://doi.org/10.19030/tlc.v8i12.6620

Wijaya, T. T., Ying, Z., Purnama, A., \& Hermita, N. (2020). Indonesian students' learning attitude towards online learning during the coronavirus pandemic. Psychology, Evaluation, and Technology in Educational Research, 3(1). https://doi.org/10.33292/petier.v3i1.56

Wijayanti, N. P. A., Damayanthi, L. P. E., Sunarya, I. M. G., \& Putrama, I. M. (2016). Pengembangan E-Modul Berbasis Project Based Learning Pada Mata Pelajaran Simulasi Digital Untuk Siswa Kelas X Studi Kasus di SMK Negeri 2 Singaraja. Jurnal Pendidikan Teknologi Dan Kejuruan, 13(2), 184-197. https://doi.org/10.23887/jptk-undiksha.v13i2.8526

Yulando, S., Sutopo, S., \& Franklin Chi, T. (2019). Electronic Module Design and Development: An Interactive Learning. American Journal of Educational Research, 7(10), 694-698. https://doi.org/10.12691/education7-10-4

Yulia, H. (2020). Online Learning to Prevent the Spread of Pandemic Corona Virus in Indonesia. ETERNAL (English Teaching Journal), 11(1). https://doi.org/10.26877/eternal.v11i1.6068

Zhou, Q., Huang, Q., \& Tian, H. (2013). Developing students' critical thinking skills by task-based learning in chemistry experiment teaching. Creative Education, 4(12). https://doi.org/10.4236/ce.2013.412A1006

Zhu, M., Bonk, C. J., \& Doo, M. Y. (2020). Self-directed learning in MOOCs: Exploring the relationships among motivation, self-monitoring, and self-management. Educational Technology Research and Development, 68(5), 2073-2093. https://doi.org/10.1007/s11423-020-09747-8 